\title{
PENGARUH PROMOSI DAN MUTASI JABATAN TERHADAP PRESTASI KERJA PEGAWAI PADA PENGADILAN NEGERI SIGLI
}

\author{
Husaini Abdullah \\ Program Studi Manajemen Fakultas Ekonomi \\ Universitas Jabal Ghafur
}

\begin{abstract}
This study aims to know and analyze the influence of Promotion and Position Mutation on Job Performance Employees in the District Court Sigli. Where the independent variables of Promotion, Job Mutation and Job Performance (Y) as dependen. The Population variable in this research is all employees of the District Court Sigli 45 employees . The entire population in the study were sampled in the study of 45 employees. Data collected in this study consisted of primary data and secondary data, both qualitative data and quantitative data and through questionnaires filled by respondents. Then the data obtained were analyzed by using multiple regression analysis . This analysis includes Normality Test, Multicolinearity Test, Heterokedasticity Test of Classic Assumption, Hypothesis Testing through F Test and T Test, and Determination Coefficient Analysis $\left(\mathrm{R}^{2}\right)$. Based on the result of research, we get regression equation: $\mathrm{Y}=$ $1,171+0,358 \mathrm{X} 1+0,388 \mathrm{X} 2$. The result of the above analysis can be concluded based on test known that Positive Promotion Variables positively and significantly influence on employee performance at Sigli District Court. This is seen from the significant value $(0,000)$ smaller than 0.05 and the value of thitung4.032> ttabel 1.682. Position Mutation variables positively and significantly influence on Employee Performance at Sigli District Court. This can be seen from the significant value (0.000) smaller than 0.05 and the value of tcount4.584> ttable1,682. Based on the calculation of the coefficient of determination (R2), indicating that the Adjusted R2 or the determinant of 0.715 means that $71.5 \%$ of Employee Performance factors can be explained by Position Promotion (X1) and Position Mutation (X2), while the remaining $28.5 \%$ can be explained by other factors not examined in this study.
\end{abstract}

Keywords: Promotion, Job Mutation, Job Performance

\section{PENDAHULUAN}

Kelangsungan suatu organisasi sangat dipengaruhi oleh sumber daya manusia (SDM) yang ada baik kualitas maupun kuantitasnya.Penanganan SDM berbeda dengan faktor produksi lainnya dikarenakan SDM selalu berkembang dan bertambah baik kuantitas maupun kualitasnya.Untuk dapat memanfaatkan SDM sesuai dengan kebutuhan organisasi, diperlukan manajemen SDM yang dapat mengatur kelangsungan suatu organisasi.

Pada umumnya suatu instansi atau organisasi pemerintahan dipengaruhi oleh faktor lingkungan, baik lingkungan internal maupun lingkungan eksternal.Lingkungan internal yaitu lingkungan yang berasal dari dalam organisasi itu sendiri, seperti SDM.Sedangkan lingkungan eksternal adalah lingkungan yang berasal dari luar organisasi tersebut, seperti politik, ekonomi, budaya, dan sosial.Untuk itu setiap instansi pemerintahan yang bergerak di berbagai bidang pada umumnya harus dapat mengendalikan kedua faktor tersebut agar tujuan instansi dapat tercapai.
Dengan semakin kompleks dan banyaknya masalah yang dihadapi oleh setiap instansi pemerintahan, maka diperlukan SDM yang mempunyai kemampuan dan keahlian dalam memberikan pelayanan publik kepada masyarakat. Berbagai cara ditempuh untuk meningkatkan kualitas pegawai agar efektivitas dan efisiensi kerja dapat tercapai, salah satu cara untuk meningkatkan kualitas dan rasa tanggung jawab pegawai dalam memberikan pelayanan publik adalah dengan adanya program pengembangan karir di lingkungan instansi pemerintahan. Adapun kebijakan pengembangan karir yang dilakukan instansi pemerintahan pada umumnya yaitu dengan melakukan program pendidikan dan pelatihan, mutasi, dan promosi jabatan.

Penilaian prestasi kerja menyediakan kesempatan, bagi pimpinan dan pegawai untuk bersama-sama meninjau perilaku karyawan yang berkaitan dengan pekerjaan, karena pada umumnya setiap orang membutuhkan dan menginginkan umpan balik tentang prestasi kerja mereka. 
Untuk mengatasi kejenuhan dan meningkatkan prestasi kerja pegawai yang belum maksimal istansi memberikan program pengembangan karier kepada pegawainya, program pengembangan karier pegawai yang diberikan seperti pemberian promosi jabatan dan mutasi jabatan.

Promosi merupakan kesempatan untuk berkembang dan maju yang dapat mendorong pegawai untuk lebih baik atau lebih bersemangat dalam melakukan suatu pekerjaan dalam lingkungan organisasi atau perusahaan. Dengan adanya promosi jabatan setiap pegawai akan merasakan bahwa dirinya benar-benar diperhatikan oleh instansi dan merasa bahwa dirinya dipercaya sehingga pegawai dapat mengembangkan apa yang dimilikinya untuk menjadi lebih baik lagi. Promosi yang dilakukan didalam instansi juga mempunyai tujuan, memberikan kesempatan kepada pegawai untuk mengembangkan kreativitas dan inovasinya yang lebih baik demi keuntungan optimal organisasi, selain itu promosi juga bertujuan untuk menambah dan memperluas pengetahuan serta pengalaman kerja para pegawai dan ini merupakan daya dorong bagi pegawai lain untuk meningkatkan prestasi kerjanya.

Pelaksanaan promosi pada Pengadilan Negeri Sigli dilaksanakan berdasarkan atas dasar prestasi kerja pegawai. Setiap pegawai yang memiliki prestasi bagus akan dipromosikan sesuai dengan kebutuhan instansi. Seorang pegawai yang akan dipromosikan harus memiliki prestasi bagus yang sesuai dengan sasaran kerja pegawai yang dilihat dari penilaian kinerja setiap pegawai, karena pegawai yang memiliki prestasi yang tinggi mempunyai peluang untuk dipromosikan.

Fenomena Promosi jabatan pada suatu instansi atau organisasi pemerintahan yang terjadi secara umum belum optimalnya pegawai yang mendapatkan promosi.Hal ini terjadi karena ada beberapa syarat yang tidak dapat dipenuhi oleh pegawai untuk mendapatkan promosi. Selain itu, kurangnya sosialisasi, transparansi dan tidak objektifnya pihak instansi berkaitan dengan kriteria promosi yang akan dilakukan. Mutasi tidak terlepas dari alasan untuk mengurangi rasa bosan pegawai kepada pekerjaan serta meningkatkan motivasi dan semangat kerja pegawai, selain itu untuk memenuhi keinginan pegawai sesuai dengan minat dan bidang tugasnya masing-masing dimana dalam kegiatan pelaksanaan mutasi kerja sering disalah tafsirkan orang yaitu sebagai hukuman jabatan atau didasarkan atas hubungan baik antara atasan dengan bawahan.

Tabel 1.1

Keadaan Pegawai Pengadilan Negeri Sigli

\begin{tabular}{|c|c|c|c|c|}
\hline $\begin{array}{l}\mathbf{N} \\
\mathbf{0}\end{array}$ & Bagian & $\begin{array}{c}\text { Pendid } \\
\text { ikan }\end{array}$ & Pangkat & Ket \\
\hline 1. & Panitera & S-1 & $\begin{array}{l}\text { Penata } \\
\text { Tk.I / III.d }\end{array}$ & \\
\hline 2. & $\begin{array}{l}\text { Wakil } \\
\text { Panitera }\end{array}$ & S-1 & $\begin{array}{l}\text { Penata } \\
\text { Tk.I / III.d }\end{array}$ & \\
\hline 3. & Sekretaris & S-2 & $\begin{array}{l}\text { Penata } \\
\text { Tk.I / III.d }\end{array}$ & \\
\hline 4. & $\begin{array}{l}\text { Panitera } \\
\text { Muda Pidana }\end{array}$ & S-1 & $\begin{array}{l}\text { Penata / } \\
\text { III.c }\end{array}$ & \\
\hline 5. & $\begin{array}{l}\text { Panitera } \\
\text { Muda } \\
\text { Perdata }\end{array}$ & $S-1$ & $\begin{array}{l}\text { Penata } \\
\text { Tk.I / III.d }\end{array}$ & \\
\hline 6. & $\begin{array}{l}\text { Panitera } \\
\text { Muda } \\
\text { Hukum }\end{array}$ & S-1 & $\begin{array}{l}\text { Penata } \\
\text { Muda Tk.I } \\
\text { / III.b }\end{array}$ & \\
\hline 7. & $\begin{array}{l}\text { Kasubbag } \\
\text { Perencanaan }\end{array}$ & S-1 & $\begin{array}{l}\text { Penata / } \\
\text { III.c }\end{array}$ & \\
\hline 8. & $\begin{array}{l}\text { Kasubbag } \\
\text { Kepegawaia } \\
\mathrm{n}\end{array}$ & SMA & $\begin{array}{l}\text { Penata } \\
\text { Muda Tk.I } \\
\text { / III.b }\end{array}$ & \\
\hline 9. & $\begin{array}{l}\text { Kasubbag } \\
\text { Umum }\end{array}$ & S-2 & $\begin{array}{l}\text { Penata } \\
\text { Muda Tk.I } \\
\text { / III.b }\end{array}$ & \\
\hline 10 & Staf Umum & S-1 & $\begin{array}{l}\text { Penata / } \\
\text { III.c }\end{array}$ & \\
\hline $\begin{array}{c}11 \\
.\end{array}$ & $\begin{array}{l}\text { Panitera } \\
\text { Pengganti }\end{array}$ & SMA & $\begin{array}{l}\text { Penata / } \\
\text { III.c }\end{array}$ & \\
\hline 12 & $\begin{array}{l}\text { Panitera } \\
\text { Pengganti }\end{array}$ & S-1 & $\begin{array}{l}\text { Penata } \\
\text { Tk.I / III.d }\end{array}$ & \\
\hline 13 & $\begin{array}{l}\text { Panitera } \\
\text { Pengganti }\end{array}$ & S-1 & $\begin{array}{l}\text { Penata } \\
\text { Tk.I / III.d }\end{array}$ & \\
\hline $\begin{array}{c}14 \\
.\end{array}$ & $\begin{array}{l}\text { Panitera } \\
\text { Pengganti }\end{array}$ & SMA & $\begin{array}{l}\text { Penata } \\
\text { Muda Tk.I } \\
\text { / III.b }\end{array}$ & \\
\hline $\begin{array}{c}15 \\
.\end{array}$ & $\begin{array}{l}\text { Panitera } \\
\text { Pengganti }\end{array}$ & SMA & $\begin{array}{l}\text { Penata } \\
\text { Muda Tk.I } \\
\text { / III.b }\end{array}$ & \\
\hline $\begin{array}{c}16 \\
.\end{array}$ & $\begin{array}{l}\text { Panitera } \\
\text { Pengganti }\end{array}$ & SMA & $\begin{array}{l}\text { Penata } \\
\text { Muda Tk.I } \\
\text { / III.b }\end{array}$ & \\
\hline $\begin{array}{c}17 \\
.\end{array}$ & $\begin{array}{l}\text { Panitera } \\
\text { Pengganti }\end{array}$ & SMA & $\begin{array}{l}\text { Penata } \\
\text { Muda Tk.I } \\
\text { / III.b }\end{array}$ & \\
\hline $\begin{array}{c}18 \\
.\end{array}$ & $\begin{array}{l}\text { Juru Sita } \\
\text { Pengganti }\end{array}$ & SMA & $\begin{array}{l}\text { Penata } \\
\text { Muda Tk.I } \\
\text { / II.b }\end{array}$ & \\
\hline $\begin{array}{c}19 \\
.\end{array}$ & Staf Umum & S-1 & $\begin{array}{l}\text { Penata } \\
\text { Muda Tk.I } \\
\text { / III.b }\end{array}$ & \\
\hline $\begin{array}{c}20 \\
.\end{array}$ & Staf Pidana & SMA & $\begin{array}{l}\text { Penata } \\
\text { Muda Tk.I } \\
\text { / III.a }\end{array}$ & \\
\hline 21 & Staf Pidana & S-1 & Penata & \\
\hline
\end{tabular}




\begin{tabular}{|c|c|c|c|c|}
\hline $\begin{array}{l}\mathbf{N} \\
\mathbf{0}\end{array}$ & Bagian & $\begin{array}{l}\text { Pendid } \\
\text { ikan }\end{array}$ & Pangkat & Ket \\
\hline 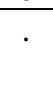 & & & $\begin{array}{l}\text { Muda Tk.I } \\
\text { / III.b }\end{array}$ & \\
\hline 22 & Staf Pidana & SMA & $\begin{array}{l}\text { Pengatur / } \\
\text { II.c }\end{array}$ & \\
\hline 23 & $\begin{array}{l}\text { Staf } \\
\text { Keuangan }\end{array}$ & SMA & $\begin{array}{l}\text { Pengatur / } \\
\text { II.c }\end{array}$ & \\
\hline 24 & $\begin{array}{l}\text { Staf } \\
\text { Keuangan }\end{array}$ & SMA & $\begin{array}{l}\text { Pengatur } \\
\text { Muda Tk.I } \\
\text { / II.b }\end{array}$ & \\
\hline 25 & Honorer & SMA & & \\
\hline 26 & Honorer & SMA & & \\
\hline 27 & Honorer & SMA & & \\
\hline 28 & Honorer & S-1 & & \\
\hline 29 & Honorer & $\begin{array}{c}\text { Diplom } \\
\mathrm{a}\end{array}$ & & \\
\hline 30 & Honorer & SMA & & \\
\hline 31 & Honorer & S-1 & & \\
\hline 32 & Honorer & S-1 & & \\
\hline 33 & Honorer & $\begin{array}{c}\text { Diplom } \\
\text { a }\end{array}$ & & \\
\hline 34 & Honorer & S-1 & & \\
\hline 35 & Honorer & S-1 & & \\
\hline 36 & Honorer & S-1 & & \\
\hline 37 & Honorer & $\begin{array}{c}\text { Diplom } \\
\mathrm{a}\end{array}$ & & \\
\hline 38 & $\begin{array}{l}\text { Honorer } \\
\text { Bakti }\end{array}$ & SMA & & \\
\hline
\end{tabular}

Sumber: Pengadilan Negeri Sigli (2016)

Selain masalah promosi jabatan, masalah lain yang dihadapi Pengadilan Negeri Sigli yaitu masalah mutasi jabatan. Pada Pengadilan Negeri Sigli pelaksanaan mutasi jabatan terhadap pegawainya dilakukan dengan mengevaluasi prestasi kerja setiap pegawainya. Dengan adanya program mutasi pada pegawai maka pegawai akan mendapatkan beban kerja yang baru, lingkungan dan suasana kerja yang baru juga.

Mutasi pada Pengadilan Negeri Sigli dilakukan agar pegawai tidak bosan terhadap suasana kerjanya ataupun agar meningkatkan prestasi kerjanya karena berada pada tempat yang tepat.Selain itu program mutasi juga dilakukan karena berbagai macam alasan seperti keinginan sendiri, penurunan prestasi kerja, mengisi kekosongan posisi dan alih tugas produktif.

Untuk mencapai prestasi kerja yang tinggi pimpinan harus memperhatikan segala hal yang berkaitan dengan peningkatan prestasi kerja yang akan menunjang pelaksanaan kerja yang lebih baik. Salah satu faktor yang mendukung untuk peningkatan prestasi kerja adalah promosi dan mutasi jabatan. Prestasi kerja yang baik tentu akan lebih mendekatkan seseorang dengan promosi sehingga akan memotivasi pegawai untuk meningkatkan prestasi guna mendapatkan promosi. Sedangkan pemberian mutasi yang baik akan dapat menempatkan pegawai pada tempat yang terpat dan menghilangkan kejenuhan pegawai yang akan dapat meningkatkan prestasi kerja pegawai.

Berdasarkan fenomena yang telah dipaparkan di atas, peneliti tertarik untuk meneliti dan membahas hal ini menjadi objek penelitian. Oleh karena itu, peneliti mengangkat judul penelitian ini adalah "Pengaruh Promosi Dan Mutasi Jabatan Terhadap Prestasi Kerja Pegawai Pada Pengadilan Negeri Sigli”.

\section{Rumusan Masalah}

Berdasarkan latar belakang yang telah diuraikan, maka perumusan masalah dalam penelitian ini adalah: Apakah Promosi dan Mutasi Jabatan berpengaruh terhadap Prestasi Kerja Pegawai Pada Pengadilan Negeri Sigli?.

\section{Tujuan Penelitian}

Tujuan penelitian ini adalah untuk mengetahui dan menganalisis pengaruh Promosi dan Mutasi Jabatan terhadap Prestasi Kerja Pegawai Pada Pengadilan Negeri Sigli.

\section{TINJAUAN PUSTAKA \\ Promosi Jabatan \\ Pengertian Promosi Jabatan}

Promosi atau kenaikan jabatan merupakan peningkatan dari seorang tenaga pegawai pada suatu bidang tugas yang lebih baik, dibandingkan dengan sebelumnya dari sisi tanggung jawab lebih besar, prestasi, fasilitas, status yang lebih tinggi, dan adanya penambahan upah atau gaji,serta tunjangan lainnya. Promosi pekerjaan atau jabatan merupakan perkembangan yang positif dari seorang pekerja atau pegawai karena tugasnya dinilai baik oleh pejabat yang berwenang.Oleh karena itu pemberian tanggung jawab dan kewenangan yang lebih tinggi patut diberikan kepada mereka yang berprestasi.Penilaian 
seorang pegawai dilakukan oleh pejabat yang membawahinya dan unit biro yang mempunyai tugas untuk mengolah kegiatan administrasi kepegawaian. (Fathoni,2006: 160 ).

Promosi jabatan memberikan peran penting bagi setiap pegawai, bahkan menjadi idaman yang selalu dinanti-nantikan.Dengan promosi berarti ada kepercayaan dan pengakuan mengenai kemampuan serta kecakapan pegawai bersangkutan untuk menduduki suatu jabatan yang lebih tinggi. Dengan demikian promosi akan memberi status sosial, wewenang ,tanggung jawab, serta penghasilan yang semakin besar bagi pegawai. Jika ada kesempatan bagi setiap pegawai dipromosikan berdasarkan azas keadilan dan objektivitas, pegawai akan terdorong bekerja giat, bersemangat, berdisiplin, dan berprestasi kerja sehingga sasaran instansi secara optimal dapat dicapai. Begitu besarnya pelaksanaan promosi pegawai maka sebaiknya pimpinan instansi harus menetapkan program promosi serta menginformasikannya kepada para pegawai.Program promosi harus memberikan informasi tentang asas-asas, dasardasar, jenisjenis, dan syarat-syarat pegawai yang dapat dipromosikan dalam instansi bersangkutan.Program promosi harus diinformasikan secara terbuka. Jika hal ini diinformasikan dengan baik, akan menjadi motivasi bagi pegawai untuk bekerja sungguhsungguh.

Menurut Siagian (2010 : 169), promosi adalah apabila seseorang dipindahkan dari satu pekerjaan ke pekerjaan lain yang tanggung jawabnya lebih besar, tingkatan hierarki jabatan lebih tinggi, dan penghasilannya pun lebih besar. Sedangkan menurut Manullang (2009:153), promosi berarti kenaikan jabatan, memerima kekuasaan dan tanggung jawab yang lebih besar dari kekuasaan dan tanggung jawab sebelumnya. Menurut Miftah Thoha (2005:33) promosi merupakan reward yang diberikan kepada pegawai yang berprestasi untuk memangku tanggung jawab yang lebih besar. Menurut Rivai (2009 : 199) promosi terjadi apabila seorang karyawan dipindahkan dari satu pekerjaan ke pekerjaan lain yang lebih tinggi dalam pembayaran, tanggung jawab, dan atau level. Umumnya diberikan sebagai penghargaan, hadiah (reward system) atas usaha dan prestasinya di masa lampau. Oleh sebab itu, maka akan muncul dua permasalahan:
1. Ketika pembuat keputusan dapat membedakan antara karyawan yang kuat dan yang lemah secara objektif.

2. Peter Principle atau Prinsip Peter, yang menyatakan bahwa secara hierarki manusia cenderung untuk terus meningkatkan tingkat kompetensinya.

Setiap pegawai mendambakan promosi karena dipandang sebagai penghargaan atas keberhasilan seseorang menunjukkan prestasi kerja yang tinggi dalam menunaikan kewajibannya dalam pekerjaan dan jabatan yang dipangkunya sekarang, sekaligus sebagai pengakuan atas kemampuan dan potensi yang bersangkutan untuk menduduki posisi yang lebih tinggi dalam organisasi. Promosi dapat terjadi tidak hanya bagi mereka yang menduduki jabatan manajerial, akan tetapi juga bagi mereka yang pekerjaannya bersifat teknikal dan nonmanajerial. Siagian (2010:170) mengatakan bahwa organisasi pada umumnya menggunakan dua kriteria utama dalam mempertimbangkan seseorang untuk dipromosikan, yaitu:

\section{Prestasi Kerja}

Promosi yang didasarkan pada prestasi kerja menggunakan hasil penilaian atas hasil karya yang sangat baik dalam promosi atau jabatan sekarang. Dengan demikian promosi tersebut dapat dipandang sebagai penghargaan organisasi atas prestasi anggotanya tersebut. Akan tetapi promosi demikian harus pula didasarkan pada pertimbangan lain, yaitu perhitungan yang matang atas potensi kemampuan yang bersangkutan menduduki posisi yang lebih tinggi.

Senioritas

Promosi berdasarkan senioritas berarti bahwa pegawai yang paling berhak dipromosikan ialah yang masa kerjanya paling lama. Banyak organisasi yang menempuh cara ini dengan tiga pertimbangan, yaitu:

a. Sebagai penghargaan atas jasa-jasa seseorang paling sedikit dilihat dari dari segi loyalitas kepada organisasi.

b. Penilaian biasanya bersifat obyektif karena cukup dengan membandingkan masa kerja orang-orang tertentu yang dipertimbangkan untuk dipromosikan.

c. Mendorong organisasi mengembangkan para pegawainya karena pegawai yang paling lama berkarya akhirnya akan mendapat promosi. Cara ini mengandung kelemahan, terutama pada kenyataan bahwa 
pegawai yang paling senior belum tentu merupakan pegawai yang paling produktif. Juga belum tentu yang paling mampu bekerja. Kelemahan tersebut memang dapat diatasi dengan adanya program pendidikan dan pelatihan, baik yang diperuntukkan bagi sekelompok pegawai yang melakukan pekerjaan-pekerjaan tertentu maupun yang secara khusus diperuntukkan bagi para pegawai senior tertentu yang akan dipertimbangkan untuk dipromosikan.

\section{Syarat - Syarat Promosi Jabatan}

Dalam mempromosikan karyawan, harus sudah dipunyai syarat-syarat tertentu yang telah direncanakan dan dituangkan dalam program promosi perusahaan.Syarat-syarat promosi harus diinformasikan kepada semua karyawan, agar mereka mengetahuinya secara jelas.Hal ini penting untuk memotivasi karyawan untuk mencapai syarat-syarat promosi tersebut. Menurut Siagian (2010:169), syarat-syarat promosi adalah sebagai berikut:

\section{Pengalaman}

Dengan pengalaman yang lebih banyak diharapkan kemampuan yang lebih tinggi, ide-ide yang lebih banyak dan sebagainya.

2. Tingkat pendidikan

Ada juga perusahaan yang mensyaratkan minimal pendidikan untuk dapat dipromosikan pada jabatan tertentu. Alasannya adalah bahwa dengan pendidikan yang lebih tinggi diharapkan pemikiran yang lebih baik.

3. Loyalitas

Dengan loyalitas yang tinggi dapat diharapkan antara lain tanggung jawab yang lebih besar.

4. Kejujuran

Untuk promosi jabatan-jabatan tertentu mungkin masalah kejujuran merupakan syarat yang penting. Misalnya untuk jabatan kasir pada umumnya syarat kejujuran merupakan syarat utama yang harus diperhatikan.

5. Tanggung jawab

Kadang-kadang sering kali suatu perusahaan diperlukan suatu tanggung jawab yang cukup besar, sehingga masalah tanggung jawab merupakan syarat utama untuk promosi jabatan.

6. Kepandaian bergaul

Misalnya jabatan untuk salesman adalah sangat penting untuk menetapkan kepandaian bergaul sebagai suatu syarat promosi jabatan.

7. Prestasi kerja
Pada umumnya setiap perusahaan selalu mencantumkan syarat untuk prestasi kinerjanya.

8. Inisiatif dan kreatif

Untuk syarat promosi jabatan terhadap jabatan tertentu, mungkin syarat tingkat inisiatif dan kreatif merupakan syarat yang harus diperhatikan. Hal ini disebabkan karena untuk jabatan tersebut sangat diperlukan inisiatif dan kreatif.

Untuk melakukan promosi, sebuah perusahaan memiliki syarat-syarat tertentu sesuaidengan kebijakan perusahaan tersebut. Hasibuan (2011:111) mengemukakan beberapa syarat umum yang biasanya dugunakan dalam promosi jabatan, yaitu :

1. Kejujuran

Karyawan harus jujur terutama pada dirinya sendiri, bawahannya, perjanjian-perjanjian dalam menjalankan atau mengelola jabatan tersebut, harus sesuai kata dengan perbuatannya.

2. Disiplin

Karyawan harus disiplin pada dirinya, tugastugasnya, serta mentaati peraturan-peraturan yang berlaku, baik tertulis maupun kebiasaan.

3. Prestasi Kerja

Karyawan itu mampu mencapai hasil kerja yang dapat dipertanggungjawabkan kualitas maupun kuantitas dan bekerja secara efektif dan efisien.

4. Kerja Sama

Karyawan dapat bekerja sama secara harmonis dengan sesama karyawan, baik horizontal maupun vertikal dalam mencapai sasaran perusahaan.

5. Kecakapan

Karyawan itu cakap, kreatif, dan inovatif dalam menyelesaikan tugas-tugas pada jabatan tersebut dengan baik.

6. Loyalitas

Karyawan harus loyal dalam membela perusahaan atau korps dari tindakan yang merugikan perusahaan atau korpsnya.

7. Kepemimpinan

Dia harus mampu membina dan memotivasi bawahannya untuk bekerja sama dan bekerja secara efektif dalam mencapai sasaran perusahaan.

8. Komunikatif

Karyawan itu dapat berkomunikasi secara efektif dan mampu menerima atau mempersepsi informasi dari atasan maupun bawahannya dengan baik, sehingga tidak terjadi miskomunikasi. 


\section{Pendidikan}

Karyawan harus telah memiliki ijazah dari pendidikan formal sesuai dengan spesifikasi jabatan.

Adapun syarat-syarat promosi jabatan menurut Nitisemito (2008: 82) adalah:

1. Pengalaman, dengan pengalaman yang lebih banyak diharapkan kemampuan yang lebih tinggi, ide yang lebih banyak dan sebagainya.

2. Tingkat pendidikan, bahwa dengan pendidikan yang lebih tinggi dapat diharapkan pemikiran yang lebih baik.

3. Loyalitas, dengan loyalitas yang tinggi dapat diharapkan tanggung jawab yang lebih besar.

4. Kejujuran, masalah kejujuran merupakan syarat yang penting, misalnya kasir pada umumnya syarat kejujuran merupakan syarat umum yang harus diperhatikan.

5. Tanggung jawab, kadang-kadang suatu perusahaan diperlukan suatu tanggung jawab yang cukup besar, sehingga masalah tanggung jawab merupakan syarat utama untuk promosi.

6. Kepandaian bergaul, untuk promosi jabatan tertentu mungkin diperlukan kepandaian bergaul, sehingga persyaratan kemampuan bergaul dengan orang lain perlu dibutuhkan untuk promosi jabatan tersebut.

7. Prestasi kerja, pada umumnya setiap perusahaan selalu mencantumkan syaratsyarat untuk prestasi kerjanya dan ini dapat dilihat dari catatan- catatan prestasi yang telah dikerjakan.

8. Inisiatif dan kreatif, syarat tingkat inisiatif dan kreatif merupakan syarat yang harus diperhatikan. Hal ini disebabkan karena untuk jabatan tersebut sangat diperlukan inisiatif dan kreatif, meskipun demikian tidak setiap perusahaan menentukan hal itu sebagai syaratnya.

\section{Jenis - Jenis Promosi Jabatan}

Jenis promosi yang dikenal Hasibuan

(2011:113) adalah:

1. Promosi Sementara (Temporary Promotion) Seorang karyawan dinaikkan jabatannya untuk sementara karena adanya jabatan yang lowong yang harus segera diisi.

2. Promosi Tetap (Permanent Promotion) Seorang karyawan dipromosikan dari satu jabatan ke jabatan yang lebih tinggi karena karyawan tersebut telah memenuhi syarat untuk dipromosikan.

\section{Promosi Kecil (Small Scale Promotion)}

Menaikkan jabatan seorang karyawan dari jabatan yang tidak sulit dipindahkan ke jabatan yang sulit yang meminta keterampilan tertentu, tetapi tidak disertai dengan peningkatan wewenang, tanggung jawab, dan gaji.

4. Promosi Kering (Dry Promotion)

Seorang karyawan dinaikkan jabatannya ke jabatan yang lebih tinggi disertai dengan peningkatan pangkat, wewenanng, dan tanggung jawab tetapi tidak disertai dengan kenaikan gaji atau upah.

Jenis-jenis promosi jabatan digunakan sesuai dengan kebutuhan instansi atau organisasi sesuai dengan kekosongan jabatan yang terdapat pada instansi atau organisasi tersebut, seperti yang dikemukakan oleh Bambang Wahyudi (2006:174) adalah sebagai berikut:

a. Promosi Sementara

Merupakan suatu bentuk promosi yang dilaksanakan untuk jangka waktu sementara. Promosi ini biasanya digunakan apabila organisasi harus mengisi suatu jabatan yang kosong untuk sementara waktu.

b. Promosi Tetap

Sebagai karyawan dipromosikan dari suatu jabatan ke jabatan yang lebih tinggi karena karyawan tersebut telah memenuhi syarat untuk dipromosikan. Sifat promosi ini tetap.

c. Promosi Kecil

Promosi yang dilaksanakan untuk meningkatkan kecakapan tenaga kerja yang bersangkutan, tetapi tidak disertai dengan peningkatan wewenang, tanggung jawab dan gaji.

d. Promosi Kering

Seorang karyawan dinaikkan jabatannya ke jabatan yang lebih tinggi disertai dengan peningkatan pangkat, wewenang, dan tanggung jawab tetapi tidak disertai dengan kenaikan gaji atau upah.

Menurut Siagian (2010:152), promosi jabatan dalam rangka untuk pengembangan karier sumber daya manusia (SDM)ada beberapa jenis promosi jabatan, yaitu:

1. Promosi jabatan struktural

Sumber daya manusia (SDM) yang telah memenuhi persyaratan kompetensi jabatan struktural tertentu dapat diberikan sertifikasi sesuai dengan pedoman yang ditetapkan oleh instansi pembina dan instansi pengendali serta dianggap telah mengikuti dan lulus pendidikan dan pelatihan kepemimpinan untuk jabatan tersebut. 
2. Promosi jabatan fungsional

Pengertian jabatan fungsional dalam suatu lembaga pendidikan dalam berbagai peraturan perundang-undangan dirumuskan sebagai suatu cara untuk melaksanakan tugas pembelajaran dan pengembangan.

Berdasarkan uraian tersebut, dapat dikatakan bahwa promosi tetap dilakukan apabila pegawai sudah memenuhi persyaratan yang telah ditentukan oleh instansi, promosi sementara dilakukan karena adanya kekosongan jabatan yang harus segera diisi, promosi kering dapat meningkatkan jabatan seseorang ke jabatan yang lebih tinggi tetapi gaji tidak naik dan promosi kecil, promosi yang dilakukan tanpa disertai kenaikan jabatan atau pangkat.

\section{METODE PENELITIAN}

\section{Lokasi dan Objek Penelitian}

Penelitian ini dilaksanakan di Pengadilan Negeri Sigli.Objek penelitian adalah Pengaruh Promosi dan Mutasi Jabatan Terhadap Prestasi Kerja Pegawai Pada Pengadilan Negeri Sigli, Jl. Tgk. Chik Ditiro No. 48 Kota Sigli Kabupaten Pidie.

\section{Populasi dan Sampel \\ Populasi}

Populasi adalah wilayah generalisasi yang terdiri atas: obyek/subyek yang mempunyai kualitas dan karakteristik tertentu yang ditetapkan oleh peneliti untuk dipelajari dan kemudian ditarik kesimpulannya. (Sugiyono, 2016: 117). Populasi dalam penelitian ini adalah seluruh pegawai Pengadilan Negeri Sigli sebanyak 45 orang pegawai.

\section{Sampel}

Sampel adalah bagian dari jumlah dan karakteristik yang dimiliki oleh populasi tersebut. Bila populasi besar, dan peneliti tidak mungkin mempelajari semua yang ada pada populasi, misalnya karena keterbatasan dana, tenaga dan waktu, maka peneliti dapat menggunakan sampel yang diambil dari populasi itu. Apa yang dipelajari dari sampel itu, kesimpulannya akan dapat diberlakukan untuk populasi. Untuk itu sampel yang diambil dari populasi harus betul-betul representatif (mewakili). (Sugiyono, 2016: 118).Pengambilan sampel dalam penelitian ini adalah menggunakan total sample yaitu seluruh populasi di jadikan sampel.Sampel penelitian ini sebanyak 45 Orang.

\section{Teknik Pengumpulan Data}

Untuk memperoleh data dan keterangan dalam penelitian maka penulis menggunakan teknik pengumpulan data sebagai berikut:

1. Kuesioner

Kuesioner merupakan teknik pengumpulan data yang dilakukan dengan cara memberi seperangkat pertanyaan atau pernyataan tertulis kepada responden untuk dijawab.

2. Wawancara

Wawancara merupakan teknik yang digunakan untuk mengumpulkan data-data atau keterangan dengan mengadakan tanya jawab kepada pihak yang mempunyai wewenang untuk memberikan data-data yang berkaitan dengan penelitian.

3. Studi Dokumentasi

Yaitu memperoleh data dengan cara meninjau, membaca, atau mempelajari dokumen-dokumen yang ada hubungannya dengan masalah yang diteliti.

\section{Skala Pengukuran Variabel}

Pengukuran masing - masing variabel dalam penelitian ini adalah dengan menggunakan skala Likert.Skala Likert digunakan untuk mengukur sikap, pendapat, dan persepsi seseorang atau kelompok orang tentang fenomena sosial.Dalam penelitian, fenomena sosial ini telah ditetapkan secara spesifik oleh peneliti, yang selanjutnya disebut sebagai variabel penelitian (Sugiyono, 2016:134).

Dengan skala Likert, maka variabel yang akan diukur dijabarkan menjadi indikator variabel. Kemudian indikator tersebut dijadikan sebagai titik tolak ukur menyusun item-item instrumen yang dapat berupa pertanyaan atau pernyataan.

\section{HASIL PENELTIAN}

Pengaruh Promosi dan Mutasi Jabatan Terhadap Prestasi Kerja Pegawai

Untuk mengetahuiPengaruh Promosi dan Mutasi Jabatan Terhadap Prestasi Kerja Pegawai Pada Pengadilan Negeri Sigli, maka dilakukan analisis data melalui regresi linear berganda.Dimana hasilnya dapat dilihat pada Tabel4.12 berikut: 
Tabel 4.12

Pengaruh Masing-masing Variabel Independen

Terhadap Variabel Dependen

Coefficients $^{a}$

\begin{tabular}{|l|c|c|c|c|c|}
\hline & \multicolumn{1}{|c|}{$\begin{array}{c}\text { Unstandardiz } \\
\text { ed } \\
\text { Coefficients }\end{array}$} & $\begin{array}{c}\text { Standar } \\
\text { dized } \\
\text { Coeffici } \\
\text { ents }\end{array}$ & & \\
\cline { 2 - 5 } Model & $\mathrm{B}$ & $\begin{array}{c}\text { Std. } \\
\text { Error }\end{array}$ & Beta & $\mathrm{t}$ & Sig. \\
\hline $1 \quad$ Constant) & 1.171 & .247 & & 4.735 & .000 \\
\begin{tabular}{l|l|l|l|} 
Promosi \\
Jabatan \\
Mutasi \\
Jabatan
\end{tabular} & .358 & .089 & .437 & 4.032 & .000 \\
\hline
\end{tabular}

a. Dependent Variable: Prestasi Kerja

Sumber: Hasil Pengolahan SPSS (2017)

Berdasarkan hasil pengolahan regresi berganda yang ditujukkan dalam Tabel 4.12, maka diperoleh hasil regresi berganda sebagai berikut:

$\mathrm{Y}=\mathrm{a}+\mathrm{b} \_1 \mathrm{X} \_1+\mathrm{b} \_2 \mathrm{X} \_2$

$\mathrm{Y}=1,171+0,358 \mathrm{X} 1+0,388 \mathrm{X} 2$

Berdasarkan persamaan tersebut dapat diuraikan sebagai berikut:

1. Konstanta (a) = 1,171 ini memiliki arti bahwa variabel promosi jabatan (X1), mutasi jabatan (X2) diobjek penelitian sama dengan nol, maka sebesarnya nilai 1,171 .

2. Koefisien $\mathrm{X} 1(\mathrm{~b} 1)=0,358$. Ini menunjukkan bahwa variabel Promosi Jabatan berpengaruh secara positif terhadap prestasi kerja pegawai pada Pengadilan Negeri Sigli, atau dengan kata lain, jika variabel Promosi Jabatan ditingkatkan, maka prestasi kerja pegawai akan bertambah sebesar 0,358 .

3. Koefisien X2 (b2) =0,388. Ini menunjukkan bahwa variabel Mutasi Jabatan berpengaruh secara positif terhadap prestasi kerja pegawai pada Pengadilan Negeri Sigli, atau dengan kata lain, jika variabel Mutasi Jabatan ditingkatkan, maka kinerja pegawai akan bertambah sebesar 0,388 .

\section{Hasil Pengujian Hipotesis Uji F}

Uji $\mathrm{F}$ dilakukan untuk melihat pengaruh variabel independen terhadap variabel dependen secara bersama-sama (secara simultan).Model hipotesis yang digunakan dalam Uji F ini adalah sebagai berikut:

1. $\mathrm{H} 0: \mathrm{b} 1, \mathrm{~b} 2,=0$ artinya secara serentak tidak terdapat pengaruh yang positif dan signifikan dari variabel bebas, Promosi
Jabatan dan Mutasi Jabatan terhadap variabel terikat (Prestasi Kerja).

2. Ha : b1, b2 = 0 artinya secara serentak terdapat pengaruh yang positif dan signifikan dari variabel bebas, Promosi Jabatan dan Mutasi Jabatan terhadap variabel terikat (Prestasi Kerja). Peneliti dalam menentukan nilai $\mathrm{F}$, maka diperlukan adanya derajat bebas pembilang dan derajat bebas penyebut, dengan rumus sebagai berikut :

$\mathrm{df}($ pembilang $)=\mathrm{k}-1$

$\mathrm{df}$ (penyebut) $=\mathrm{n}-\mathrm{k}$

keterangan :

$\mathrm{n}=$ jumlah sampel penelitian

$\mathrm{k}=$ jumlah variabel bebas dan terikat

Padapenelitian ini diketahui jumlah sampel

(n) adalah 45 dan jumlah keseluruhan variabel (k) adalah 3, sehingga diperoleh:

1) $\mathrm{df}$ (pembilang) $=\mathrm{k}-1 \quad \mathrm{df}$ (pembilang) $=3-1=2$

2) $\mathrm{df}$ (penyebut) $=\mathrm{n}-\mathrm{k} \quad \mathrm{df}$ (penyebut) $=$ $45-3=42$

Nilai Fhitung akan diperoleh dengan bantuan software SPSS 17.0 for Windows, kemudian akan dibandingkan dengan nilai Ftabel pada tingkat $\alpha=5 \%(2: 42)=3,22$ (berdasarkan Ftabel), dengan kriteria sebagai berikut:

a) $\mathrm{H} 0$ diterima jika Fhitung $<$ Ftabel pada $\alpha$ $=5 \%$

b) H0 ditolak jika Fhitung > Ftabel pada $\alpha$ $=5 \%$

Tabel 4.13

Hasil Analisis Uji F

ANOVA $^{b}$

\begin{tabular}{|c|c|c|c|c|c|}
\hline Model & $\begin{array}{c}\text { Sum of } \\
\text { Squares }\end{array}$ & df & $\begin{array}{c}\text { Mean } \\
\text { Square }\end{array}$ & F & Sig. \\
\hline $1 \begin{array}{l}\text { Regressi } \\
\text { on }\end{array}$ & 4.132 & 2 & 2.066 & 56.103 & $.000^{\mathrm{a}}$ \\
$\begin{array}{l}\text { Residual } \\
\text { Total }\end{array}$ & 1.547 & 42 & .037 & & \\
\hline
\end{tabular}

a. Predictors: (Constant), Mutasi Jabatan, Promosi

Jabatan

b. Dependent Variable: Prestasi Kerja

Sumber: Hasil Pengolahan SPSS (2017) 
Berdasarkan tabel 4.13 dapat dilihat Fhitung adalah 56,103 dengan tingkat signifikan 0,000 . Oleh karena itu, pada kedua perhitungan yaitu Fhitung $>$ Ftabel $(56,103>3,22)$ dan tingkat signifikansinya $0,000<0,05$. Hal ini menunjukkan bahwa $\mathrm{H} 0$ ditolak dan $\mathrm{Ha}$ diterima, yang artinya variabel bebas, yang terdiri dari Promosi Jabatan dan Mutasi Jabatan secara bersama-sama berpengaruh positif dan signifikan terhadap variabel terikat (Prestasi kerja pegawai pada Pengadilan Negeri Sigli).

\section{Uji t}

Uji tdilakukan untuk melihat signifikan dari pengaruh variabel independen secara individu terhadap variabel dependen (secara parsial). Model hipotesis yang akan dilakukan adalah sebagai berikut :

1. $\mathrm{H} 0: \mathrm{b} 1=\mathrm{b} 2=0$, artinya secara parsial tidak terdapat pengaruh yang positif dan signifikan dari variabel independen terhadap variabel dependen.

2. $\mathrm{H} 0: \mathrm{b} 1 \neq 2 \neq 0$, artinya secara parsial terdapat pengaruh yang positif dan signifikan dari variabel independen terhadap variabel dependen. Kriteria pengambilan keputusan adalah:
a) $\mathrm{HO}$ diterima jika thitung $<$ ttabel pada $\alpha=5 \%$
b) H0 ditolak jika thitung $>$ ttabel $\alpha=5 \%$

Tingkat kesalahan $(\alpha)=5 \%$ dan derajat kebebasan $(\mathrm{df})=(\mathrm{n}-\mathrm{k})$

$\mathrm{n}=$ jumlah sampel, $\mathrm{n}=45$

$\mathrm{k}=$ jumlah variabel yang digunakan, $\mathrm{k}=3$

Maka: derajat bebas (df) $=n-k=45-3=42$

Uji t yang digunakan adalah uji dua arah, maka ttabel yang digunakan adalah t0,05(42) =1,682 .

Tabel 4.14

Hasil Analisis Uji t

Coefficients $^{\mathrm{a}}$

\begin{tabular}{|c|c|c|c|c|c|}
\hline \multirow[b]{2}{*}{ Model } & \multicolumn{2}{|c|}{$\begin{array}{l}\text { Unstandardi } \\
\text { zed } \\
\text { Coefficients }\end{array}$} & \multirow{2}{*}{\begin{tabular}{|c}
$\begin{array}{c}\text { Standar } \\
\text { dized } \\
\text { Coeffici } \\
\text { ents }\end{array}$ \\
Beta \\
\end{tabular}} & \multirow[b]{2}{*}{$\mathrm{t}$} & \multirow[b]{2}{*}{ Sig. } \\
\hline & B & $\begin{array}{l}\text { Std. } \\
\text { Error }\end{array}$ & & & \\
\hline 1 (Constant) & 1.171 & .247 & & 4.735 & .000 \\
\hline $\begin{array}{l}\text { Promosi } \\
\text { Jabatan }\end{array}$ & .358 & .089 & .437 & 4.032 & .000 \\
\hline $\begin{array}{l}\text { Mutasi } \\
\text { Jabatan }\end{array}$ & .388 & .085 & .497 & 4.584 & .000 \\
\hline
\end{tabular}

Coefficients $^{a}$

\begin{tabular}{|l|c|c|c|c|c|}
\hline & $\begin{array}{c}\text { Unstandardi } \\
\text { zed } \\
\text { Coefficients }\end{array}$ & $\begin{array}{c}\text { Standar } \\
\text { dized } \\
\text { Coeffici } \\
\text { ents }\end{array}$ & & \\
\cline { 2 - 4 } Model & $\mathrm{B}$ & $\begin{array}{c}\text { Std. } \\
\text { Error }\end{array}$ & Beta & $\mathrm{t}$ & Sig. \\
\hline 1 (Constant) & 1.171 & .247 & & 4.735 & .000 \\
$\begin{array}{l}\text { Promosi } \\
\text { Jabatan } \\
\text { Mutasi } \\
\text { Jabatan }\end{array}$ & .358 & .089 & .437 & 4.032 & .000 \\
\hline
\end{tabular}

a. Dependent Variable: Prestasi Kerja

Sumber: Hasil Pengolahan SPSS (2017)

Berdasarkan Tabel 4.14 menunjukkan bahwa:

1. Variabel Promosi Jabatan berpengaruh secara positif dan signifikan terhadap Prestasi Kerja pegawai pada Pengadilan Negeri Sigli. Hal ini terlihat dari nilai signifikan $(0,000)$ lebih kecil dari 0,05 dan nilai thitung 4,032>ttabel 1,682.

2. Variabel Mutasi Jabatan berpengaruh secara positif dan signifikan terhadap Prestasi Kerja pegawai pada Pengadilan Negeri Sigli. Hal ini terlihat dari nilai signifikan $(0,000)$ lebih kecil dari 0,05 dan nilai thitung4,584> ttabel1,682.

\section{Identifikasi Determinan (R2)}

Determinan digunakan untuk melihat seberapa besar pengaruh variabel independent terhadap variabel dependent. Jika determinan (R2) semakin besar atau mendekati satu, maka pengaruh variabel independent (X1, X2) terhadap variabel terikat (Y) semakin kuat. Jika determinan (R2) semakin kecil atau mendekati nol maka pengaruh variabel independent (X1, X2) terhadap variabel dependent (Y) semakin lemah.

Tabel 4.15

Uji Koefisien Determinasi (R2) Model Summary ${ }^{b}$

\begin{tabular}{|c|c|c|c|c|c|}
\hline Model & $\mathrm{R}$ & $\begin{array}{c}\mathrm{R} \\
\text { Square }\end{array}$ & $\begin{array}{l}\text { Adjusted } \\
\text { R Square }\end{array}$ & $\begin{array}{c}\text { Std. Error } \\
\text { of the } \\
\text { Estimate }\end{array}$ & $\begin{array}{l}\text { Durbin- } \\
\text { Watson }\end{array}$ \\
\hline 1 & $.853^{a}$ & .728 & .715 & .19190 & 2.152 \\
\hline
\end{tabular}


Model Summary ${ }^{\mathbf{b}}$

\begin{tabular}{|c|c|c|c|c|c|}
\hline Model & $\mathrm{R}$ & $\begin{array}{c}\mathrm{R} \\
\text { Square }\end{array}$ & $\begin{array}{l}\text { Adjusted } \\
\text { R Square }\end{array}$ & $\begin{array}{c}\text { Std. Error } \\
\text { of the } \\
\text { Estimate }\end{array}$ & $\begin{array}{l}\text { Durbin- } \\
\text { Watson }\end{array}$ \\
\hline 1 & $.853^{\mathrm{a}}$ & .728 & .715 & .19190 & 2.152 \\
\hline
\end{tabular}

a. Predictors: (Constant), Mutasi Jabatan, Promosi Jabatan

b. Dependent Variable: Prestasi Kerja

Sumber: Hasil Pengolahan SPSS (2017)

Tabel 4.15 menunjukkan bahwa nilai $\mathrm{R}=$ 0,853 berarti hubungan antara variabel Promosi Jabatan dan Mutasi Jabatan variabel dependent Prestasi Kerja pegawai sebesar 85,3\%, artinya hubungannya sangat erat. Angka $\mathrm{R}$ Square sebesar 0,728 berarti 72,8\% faktor-faktor Prestasi Kerja pegawai dapat dijelaskan oleh Promosi Jabatan dan Mutasi Jabatan sedangkan sisanya $27,2 \%$ dapat dijelaskan oleh faktorfaktor lain yang tidak diteliti dalam penelitian ini. Angka Adjusted R2 atau determinan sebesar 0,715 berarti $71.5 \%$ faktor-faktor Prestasi Kerja pegawai dapat dijelaskan oleh Promosi Jabatan (X1) dan Mutasi Jabatan (X2), sedangkan sisanya $28,5 \%$ dapat dijelaskan oleh faktorfaktor lain yang tidak diteliti dalam penelitian ini.

\section{DAFTAR PUSTAKA}

Arikunto, Suharsimi. 2003. Prosedur Penelitian; Suatu Pendekatan Praktek, EdisiRevisi VI. Jakarta: PT. Rineka Cipta.

Armanu Thoyib 2010 "Hubungan Kepemimpinan, Budaya, Stategi, dan Kinerja" Fakultas Ekonomi Universitas Brawijaya Malang.

Gomes Cardoso, Faustino. 2001. Manajemen Sumber Daya Manusia (cetakan V). Yogyakarta: CV Andi Offiset.

Hasibuan dan Melayu S.P. (2002), Manajemen Sumber Daya Manusia : Dasar dan Kunci Keberhasilan, Gunung Agung Jakarta.

Kreitner Robert, Kinicki Angelo, 2005. Organizational Behavior (Terjemahan) Buku 1, Edisi Kelima, Salemba Empat, Jakarta.
M.Wahyuddin, Vera Parlinda 2010 "Pengaruh Kepemimpinan, Motivasi, Pelatihan, Dan Lingkungan Kerja Terhadap Kinerja Karyawan Pada Perusahaan Daerah Air Minum Kota Surakarta" Program Pascasarjana Universitas Muhammadiyah Surakarta.

Mangkuprawira, syafri. 2001. Manajemen Sumber Daya Manusia Strategik, Jakarta: Ghalia Indonesia .

Mangkuprawira, Syafri. 2001. Metode Kuantitatif, Teori dan Aplikasi untuk Bisnis dan Ekonom (Cetakan 1). Yogyakarta: AMP YKPN

Mathis, Robert L, Jackson, John H 2002. Manajemen Sumber Daya Manusia.Jakarta : Salemba Empat

Muhammad Anas 2010 "Pengaruh Motivasi Terhadap Kinerja Pegawai Pada Kantor Balai Perbenihan Tanaman Hutan Sulawesi” Universitas Sawerigading Makassar.

Komang Ardana, Ni Wayan Mujiati, Anak Agung Ayu Sriathi Perilaku Keorganisasian Buku 1(2008) Penerbit Graha Ilmu Candi Gebang Permai Blok R/6 Yogyakarta 55511 Edisi Pertama.

Rivai, Veitha dan Deddy Mulyadi.(2009). Kepemimpinan dan Perilaku Organisasi. EdisiKetiga, PT. Raja Grafindo Persada. Jakarta.

Rivai, Veithal. 2003. Kepemimpinan dan Perilaku Organisasi (Cetakan Pertama), Jakarta: PT Raja Grafindo Persada.

Robbinss Stephen P., 2001. Organizational Behavior(Terjemahan) Jilid 1, Edisi Kedelapan, PT.Bhuana Ilmu Populer, Jakarta.

Robbinss Stephen P., 2006. Essentials of OrganizationalBehavior (Terjemahan), Edisi Kelima,Penerbit Erlangga, Jakarta.

Sondang P. Siagian, 2001. Kiat Meningkatkan ProduktivitasKerja, Cetakan Pertama, PT. RinekaCipta, Jakarta. 
Supardi, Anwar. 2002. Dasar-dasar Perilaku Organisasi (Cetakan Pertama). Yogyakarta: UII Press.

T.Hani, Handoko (2000) strategi organisasi, Amara books yogyakartawww.google.com. artikel manajemen blogspot 25/03/2011.www.google.com.http://Met rotvnews.com/index.php/metromain/ne wsscat/polkam/2010.www.google.com. http://Teorionline.wordpress.com 25/01/2011/ Definisi Kepuasan Kerja.

Rencana Strategis (RENSTRA) Badan Perencanaan Pembangunan Daerah (BAPPEDA) Kabupaten Pidie Tahun 2007-2012. 